\title{
Nutritional quality of children's school lunches: differences according to food source
}

\author{
Jennifer P Taylor ${ }^{1, *}$, Kimberley J Hernandez ${ }^{1}$, Jane Mary Caiger ${ }^{2}$, Donna Giberson ${ }^{3}$, \\ Debbie MacLellan ${ }^{1}$, Marva Sweeney-Nixon ${ }^{3}$ and Paul Veugelers ${ }^{4}$ \\ 'Department of Applied Human Sciences, University of Prince Edward Island, 550 University Avenue, \\ Charlottetown, PE, Canada, C1 A 4P3: ${ }^{2}$ PEI Healthy Eating Alliance, Charlottetown, PE, Canada: ${ }^{3}$ Department \\ of Biology, University of Prince Edward Island, Charlottetown, PE, Canada: ${ }^{4}$ School of Public Health, University \\ of Alberta, Edmonton, AB, Canada
}

Submitted 26 July 2011: Final revision received 23 January 2012: Accepted 1 February 2012: First published online 2 April 2012

\begin{abstract}
Objective: To assess the nutritional quality of lunchtime food consumption among elementary-school children on Prince Edward Island according to the source of food consumed (home $v$. school).

Design: Students completed a lunchtime food record during an in-class survey. Dietary adequacy was assessed by comparing median micronutrient intakes with one-third of the Estimated Average Requirement; median macronutrient intakes were compared with the Acceptable Macronutrient Distribution Ranges. The Wilcoxon signed rank test was used to assess differences in nutrient intakes according to source of food consumed.

Setting: Elementary schools in Prince Edward Island, Canada.

Subjects: Grade 5 and 6 students ( $n$ 1980).

Results: Foods purchased at school were higher in nutrient density for ten micronutrients $\left(\mathrm{Ca}, \mathrm{Mg}, \mathrm{K}, \mathrm{Zn}\right.$, vitamin $\mathrm{A}$, vitamin $\mathrm{D}$, riboflavin, niacin, vitamin $\mathrm{B}_{6}$ and vitamin $\mathrm{B}_{12}$ ) compared with packed lunch foods from home, which were higher in three micronutrients (Fe, vitamin $\mathrm{C}$ and folate). School lunches provided sufficient protein but were higher in sugar and fat than home lunches. Foods brought from home were higher in carbohydrates, fibre and $\mathrm{Na}$ than foods purchased at school.

Conclusions: The overall nutritional quality of lunches was poor, regardless of source. A significant proportion of foods consumed by the students came from home sources; these were lower nutritional quality and were higher in $\mathrm{Na}$ than foods offered at school. Findings suggest that improving the dietary habits of school-aged children will require a collaborative effort from multiple stakeholders, including parents.
\end{abstract}

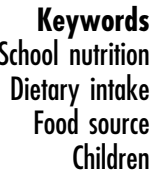

Keywords Dietary intake Children
Experts agree that having access to healthy foods while at school can enable children to develop healthy eating habits and reduce childhood obesity ${ }^{(1-5)}$. Unfortunately, children face a variety of challenges while trying to 'eat healthy' during time spent at school owing to the ready availability of high-fat and high-sugar foods. One common strategy to improve children's eating habits is to reduce or remove access to unhealthy foods at the school level ${ }^{(6)}$ through school food and nutrition policies (SFNP).

The development of SFNP is increasingly viewed as an important strategy to improve eating habits and reduce childhood obesity ${ }^{(1,3-7)}$. In 2006, all elementary (grade 1-6) and consolidated (grade 1-8) schools in Prince Edward Island (PEI), Canada adopted nutrition policies. The PEI SFNP addresses such issues as the quality of food available in the school environment, student access to food, food used in school fundraising initiatives, food safety and nutrition education. The policy regulations include food lists that classify specific food items e.g. French fries and pizza according to the allowed frequency of consumption, as 'every day', 'sometimes' and 'once in a while' foods. Specific nutrient criteria are not included in the SNFP food lists; instead, food descriptions such as 'low fat hot dogs' or 'lower sodium soups' are included.

A major gap in our understanding of how nutrition policies affect children's dietary intakes is information on the nutritional quality of lunchtime food choices, and how this is influenced by the source of the child's lunch (combination of home and school). Most SFNP evaluations have assessed impact on overall children's dietary 
intake (at home and at school). Although there is growing evidence that home packed lunches are of lower nutritional quality than national school lunch programme standards ${ }^{(8-11)}$, there are no Canadian studies which have examined the nutrient composition of children's lunchtime food intake. Since there is no national school food programme in Canada, elementary-school lunch programmes are ad hoc and volunteer driven with limited menu selection of sandwiches or pizza from either outside caterers or prepared on site by volunteers. Further, students may also purchase milk at a subsidized price. As a result, a large number of PEI children take a packed lunch from home and supplement this with foods and/or beverages purchased at school ${ }^{(12)}$. Assessing the nutritional content of children's lunch foods according to the source of food is thus important and will help enhance our understanding of the role of parents and schools in improving the nutritional quality of children's school lunches. Specifically, it is important to compare the quality of food provided at school, which depends on the level of adherence to the policies, with the quality of food provided from home, which is influenced by such factors as the nature of foods available ${ }^{(13)}$, parental food practices $^{(14)}$, knowledge about nutrition and student food preferences ${ }^{(15)}$. The present study describes the nutritional quality of lunchtime food consumption among grade 5 and 6 children on PEI and assesses differences in nutritional quality according to the source of food consumed (home $v$. school).

\section{Methods}

\section{Sample}

In 2007, there were fifty-two elementary (grade 1-6) and consolidated (grade 1-8) schools in PEI. Schools that had no students in grades 5 and 6 were eliminated from the sample as were a small number of French-language schools, leaving a total of forty-four schools. Students below grade 5 are less likely to provide valid dietary data $^{(16,17)}$ and thus were not invited to participate. All grade 5 and 6 students in the forty-four schools were invited to participate in the research. Only those students whose parents had returned signed consent forms and had completed the parent surveys were included in the study. A total of 2036 out of 3320 grade 5 and 6 students had permission to participate in the present study representing a $61 \%$ response rate after accounting for absent or sick children on the day of the survey. Fifty-six (2.8\%) questionnaires were eliminated due to unreliable dietary data or missing or incomplete parental consent forms leaving a total of 1980 lunchtime food records (LFR; $60 \%$ ). The final sample included 1006 boys (49.7\%) and 1020 girls $(50 \cdot 4 \%)$. The sample was distributed evenly between grades with 1039 grade 5 students (49.2\%) and 1072 grade 6 students $(50 \cdot 8 \%)$.

\section{Data collection}

An in-class cross-sectional survey was used to assess children's lunchtime food consumption and the source of foods/beverages consumed among grade 5 and 6 students in PEI. Data were collected in the winter of 2007. The study protocol was approved by the University of Prince Edward Island Research Ethics Board.

Students were asked to recall foods and beverages consumed during school lunch for one day using a previously validated LFR method ${ }^{(18)}$. When data collection was in the afternoon, the present day's lunch was reported (on-third of students); when data collection occurred in the morning, children were asked to recall foods consumed at the previous day's lunch (two-thirds of students). Students who reported lunches for the previous day had small but significantly higher intakes of most micronutrients compared with student's intakes recorded the same day as data collection (date not shown). Data collection was not conducted on Monday mornings or Fridays so as to increase the validity of self-reported data and to accommodate the schools' schedules. Trained individuals provided students with instructions and a sample of a completed LFR as well as assistance with recalling and spelling food and beverage items. Students indicated how many servings they ate, the source of the food (school lunch, milk programme, vending machine, home, 'other' source) and details about foods and beverages consumed (i.e. brands, flavours, condiments). All completed LFR were reviewed by trained research assistants to identify missing or unclear information.

\section{Data analyses}

All foods and beverages consumed were coded using the 2007 version of the Canadian Nutrient File ${ }^{(19)}$. Information was obtained from schools and fast-food outlets, if applicable, regarding serving sizes (e.g. size and type of submarine sandwich; volume of carton of milk). When children were unable to provide sufficiently detailed descriptions of foods and beverages consumed, standard coding rules were applied using foods and/or serving sizes which are commonly consumed by Canadian children in this age group ${ }^{(20)}$. Cross-referencing of coding was performed by the two trained research assistants to increase consistency. All foods and beverages were then entered into the CANDAT nutrient analysis program ${ }^{(21)}$ and cross-checked with those originally recorded on the LFR. Standard macro- and micronutrients were then generated using CANDAT software. Nutrient data were examined for extreme values and duplicate entries using the SAS statistical software package version 9.1 (SAS Institute Inc., Cary, NC, USA). Extreme values were identified using SAS univariate analysis and checked against the original LFR and nutrient analysis printouts to ensure that they did not arise from errors in coding or data entry. Any identified errors were corrected; if the extreme value reflected an unreliable record, it was deleted. Duplicate entries were also identified and deleted. 
Due to a low number of foods/beverages from 'vending' and 'other' sources, the 'source' variable was re-coded so that foods/beverages from vending machines were included with 'school foods' and 'other' foods (usually fast food taken to school by parents) were then included with 'home foods'.

Descriptive statistics were generated for energy $(\mathrm{kJ} /$ $\mathrm{kcal}$ ), micronutrients ( $\mathrm{Ca}$, folate, $\mathrm{Mg}$, niacin, $\mathrm{K}$, riboflavin, thiamin, vitamin $\mathrm{A}$, vitamin $\mathrm{B}_{6}$, vitamin $\mathrm{B}_{12}$, vitamin $\mathrm{C}$, vitamin $\mathrm{D}$, vitamin $\mathrm{E}$ and $\mathrm{Zn}$ ), macronutrients (carbohydrates, fat and protein), fibre and total sugars. The dietary quality of lunches was assessed by comparing median micronutrient, protein, $\mathrm{Ca}$ and vitamin $\mathrm{D}$ intakes to onethird $(>33 \%)$ of the Estimated Average Requirement $(\mathrm{EAR})^{(22)}$, since there is no national school lunch programme in Canada and therefore no standard as in the USA. When the EAR was not available for specific nutrients such as $\mathrm{K}, \mathrm{Na}$ and fibre, the median intakes were compared with one-third of the Adequate Intake (AI) ${ }^{(23)}$. Given that the majority of foods consumed were brought from home, nutrient intakes from foods brought from home were higher than from foods purchased at school. Therefore, nutrient densities (nutrients per $4184 \mathrm{~kJ} /$ $1000 \mathrm{kcal})^{(24)}$ were calculated for foods consumed from school and from home to standardize the nutrients from the two sources. While definitions of nutrient density vary, it is often defined as the nutrient content (in grams or $\mathrm{mg}$ ) of a food or meal divided by the total energy content (expressed in kilojoules/kilocalories) ${ }^{(24)}$.
Since the distribution of intakes for all nutrients assessed differed substantially from a normal distribution and could not be normalized by log or square-root transformation, differences in nutrient intakes from foods brought from home $v$. purchased at school within each child were assessed using the Wilcoxon signed rank test. The Wilcoxon rank sum test was used to assess differences in nutrient densities of foods according to sex. The $\chi^{2}$ test was used to assess associations between the adequacy of lunchtime nutrient intakes and sex. A $P$ value of 0.05 was used to define statistical significance.

\section{Results}

Analysis revealed that total median lunchtime intakes of $\mathrm{Ca}, \mathrm{Mg}, \mathrm{Zn}$, vitamins $\mathrm{A}, \mathrm{D}, \mathrm{C}, \mathrm{B}_{6}$ and folate fell below recommended levels (one-third of the RDA; Table 1). $\mathrm{K}$ intakes fell below the recommended AI level whereas $\mathrm{Na}$ intakes exceeded one-third of the AI $(939 \mathrm{mg}$ ); the levels were so high that they exceeded one-third of the Tolerable Upper Intake Level (UL; $733.3 \mathrm{mg}$ ) which is the highest daily intake level identified as being associated with no increased health risk ${ }^{(22)}$. In contrast, median fibre intakes were well below one-third of the AI (Table 1). More than $50 \%$ of the children consumed lunches that did not meet one-third of the recommended nutrient intakes (EAR or AI) for $\mathrm{Mg}, \mathrm{Zn}$, vitamin $\mathrm{A}$, vitamin $\mathrm{C}$, vitamin $\mathrm{B}_{6}$,

Table 1 Total lunchtime nutrient intakes by source of food consumed* for grade 5 and 6 children ( $n$ 1980) in elementary schools, Prince Edward Island, Canada

\begin{tabular}{|c|c|c|c|c|c|c|c|c|}
\hline \multirow[b]{2}{*}{ Nutrient } & \multirow{2}{*}{$\begin{array}{l}\text { Recommended } \\
\text { nutrient intake }\end{array}$} & \multicolumn{2}{|c|}{ Total } & \multicolumn{2}{|c|}{ Home } & \multicolumn{2}{|c|}{ School } & \multirow[b]{2}{*}{$P$ valuet } \\
\hline & & Mean & SD & Mean & SD & Mean & SD & \\
\hline Weight (g) & & $502 \cdot 5$ & $219 \cdot 2$ & $323 \cdot 5$ & $239 \cdot 2$ & $176 \cdot 4$ & $210 \cdot 8$ & $<0.0001$ \\
\hline Energy (kJ) & & 2305 & 1035 & 1605 & 1122 & 696 & 947 & $<0.0001$ \\
\hline Energy (kcal) & & $551 \cdot 0$ & $247 \cdot 4$ & $383 \cdot 6$ & $268 \cdot 1$ & $166 \cdot 3$ & $226 \cdot 4$ & $<0.0001$ \\
\hline Protein (g) & $11 \cdot 3$ & $19 \cdot 1$ & $11 \cdot 3$ & $12 \cdot 2$ & $11 \cdot 2$ & $6 \cdot 84$ & $8 \cdot 9$ & $<0.0001$ \\
\hline Fat $(\mathrm{g})$ & & $18 \cdot 8$ & $11 \cdot 2$ & $12 \cdot 6$ & $11 \cdot 3$ & $6 \cdot 2$ & $9 \cdot 0$ & $<0.0001$ \\
\hline Carbohydrates (g) & & $77 \cdot 8$ & $38 \cdot 6$ & $56 \cdot 2$ & $40 \cdot 8$ & $21 \cdot 1$ & $31 \cdot 1$ & $<0.0001$ \\
\hline Sugar (g) & & $36 \cdot 1$ & $24 \cdot 0$ & $24 \cdot 1$ & $22 \cdot 7$ & $11 \cdot 8$ & $17 \cdot 5$ & $<0.0001$ \\
\hline Fibre $(\mathrm{g})$ & $8 \cdot 7 q, 10 \cdot 30^{-1}$ & $4 \cdot 17$ & $2 \cdot 77$ & $3 \cdot 10$ & $2 \cdot 70$ & $1 \cdot 04$ & $1 \cdot 80$ & $<0.0001$ \\
\hline $\mathrm{Fe}(\mathrm{mg})$ & $2 \cdot 7$ & $3 \cdot 4$ & $2 \cdot 0$ & $2 \cdot 5$ & $2 \cdot 1$ & $0 \cdot 85$ & $1 \cdot 5$ & $<0.0001$ \\
\hline $\mathrm{Ca}(\mathrm{mg})$ & 433 & $306 \cdot 7$ & $206 \cdot 0$ & $147 \cdot 6$ & $154 \cdot 4$ & $158 \cdot 8$ & $189 \cdot 4$ & $<0.0001$ \\
\hline $\mathrm{Mg}(\mathrm{mg})$ & 80 & $65 \cdot 9$ & $37 \cdot 9$ & $42 \cdot 3$ & $35 \cdot 8$ & $23 \cdot 4$ & $30 \cdot 9$ & $<0.0001$ \\
\hline $\mathrm{K}(\mathrm{mg})$ & 1500 & $695 \cdot 9$ & $384 \cdot 9$ & $412 \cdot 3$ & $343 \cdot 1$ & $281 \cdot 8$ & $355 \cdot 8$ & $<0.0001$ \\
\hline $\mathrm{Zn}(\mathrm{mg})$ & $2 \cdot 7$ & $2 \cdot 3$ & $1 \cdot 4$ & $1 \cdot 4$ & $1 \cdot 3$ & 0.87 & $1 \cdot 1$ & $<0.0001$ \\
\hline Vitamin A (RAE) & 200 & $128 \cdot 1$ & $145 \cdot 4$ & $56 \cdot 4$ & $115 \cdot 3$ & $71 \cdot 8$ & $104 \cdot 9$ & $<0.0001$ \\
\hline Vitamin $D(\mu g)$ & $1 \cdot 7$ & $1 \cdot 5$ & $1 \cdot 6$ & $0 \cdot 3$ & 0.9 & $1 \cdot 1$ & $1 \cdot 4$ & $<0.0001$ \\
\hline Vitamin C (mg) & 15 & $34 \cdot 3$ & $43 \cdot 7$ & $27 \cdot 8$ & $40 \cdot 5$ & $6 \cdot 4$ & $22 \cdot 5$ & $<0.0001$ \\
\hline Thiamin (mg) & $0 \cdot 3$ & 0.41 & 0.25 & 0.29 & $0 \cdot 25$ & $0 \cdot 12$ & $0 \cdot 19$ & $<0.0540$ \\
\hline Riboflavin (mg) & $0 \cdot 3$ & 0.57 & 0.34 & $0 \cdot 31$ & $0 \cdot 27$ & $0 \cdot 26$ & $0 \cdot 31$ & $<0.0001$ \\
\hline Niacin (mg) & $4 \cdot 0$ & $7 \cdot 7$ & $5 \cdot 3$ & $5 \cdot 3$ & $5 \cdot 3$ & $2 \cdot 4$ & $3 \cdot 6$ & 0.0002 \\
\hline Vitamin $B_{6}(\mathrm{mg})$ & 0.3 & 0.29 & 0.22 & $0 \cdot 20$ & $0 \cdot 20$ & 0.09 & $0 \cdot 14$ & $<0.0001$ \\
\hline Vitamin $B_{12}(\mu \mathrm{g})$ & 0.6 & 0.98 & 0.92 & 0.44 & 0.77 & 0.53 & 0.67 & $<0.0001$ \\
\hline Folate $(\mu \mathrm{g})$ & 100 & $98 \cdot 9$ & $70 \cdot 3$ & $74 \cdot 6$ & $69 \cdot 9$ & $24 \cdot 2$ & $45 \cdot 8$ & $<0.0001$ \\
\hline $\mathrm{Na}(\mathrm{mg})$ & 500 & $1027 \cdot 0$ & $625 \cdot 0$ & $758 \cdot 4$ & $673 \cdot 3$ & $266 \cdot 8$ & $462 \cdot 0$ & $<0.0001$ \\
\hline
\end{tabular}

RAE, retinol activity equivalents; $q$, females; $\hat{o}$, males.

*Source of food consumed was determined by combining vending machine and school lunch into one category and combining home and 'other sources' into another category.

tDifferences assessed using a Wilcoxon signed rank test. 
Table 2 Proportion consuming adequate* micronutrient intakes at lunch by sex among grade 5 and 6 children $(n 1980)$ in elementary schools, Prince Edward Island, Canada

\begin{tabular}{|c|c|c|c|c|c|c|c|}
\hline \multirow[b]{2}{*}{ Nutrient } & \multicolumn{2}{|c|}{ Total } & \multicolumn{2}{|c|}{ Male } & \multicolumn{2}{|c|}{ Female } & \multirow[b]{2}{*}{$P$ value } \\
\hline & $n$ & $\%$ & $n$ & $\%$ & $n$ & $\%$ & \\
\hline Protein $(\mathrm{g})$ & 1349 & $68 \cdot 3$ & 670 & $68 \cdot 4$ & 679 & $68 \cdot 1$ & 0.8737 \\
\hline $\mathrm{Fe}(\mathrm{mg})$ & 1506 & $76 \cdot 2$ & 775 & $79 \cdot 2$ & 731 & $73 \cdot 3$ & 0.0023 \\
\hline $\mathrm{Mg}(\mathrm{mg})$ & 838 & $42 \cdot 3$ & 418 & $42 \cdot 7$ & 420 & $42 \cdot 1$ & 0.7976 \\
\hline $\mathrm{Zn}(\mathrm{mg})$ & 818 & $41 \cdot 3$ & 412 & $42 \cdot 1$ & 406 & $40 \cdot 7$ & 0.5390 \\
\hline Vitamin A (RAE) & 812 & $41 \cdot 5$ & 338 & $34 \cdot 5$ & 474 & $47 \cdot 5$ & $<0.0001$ \\
\hline Vitamin C (mg) & 897 & $45 \cdot 4$ & 443 & $45 \cdot 3$ & 454 & $45 \cdot 5$ & 0.8983 \\
\hline Thiamin (mg) & 1522 & $77 \cdot 1$ & 776 & $79 \cdot 3$ & 746 & $74 \cdot 8$ & $0 \cdot 0190$ \\
\hline Riboflavin (mg) & 1565 & $79 \cdot 2$ & 793 & $81 \cdot 0$ & 772 & $77 \cdot 4$ & 0.0507 \\
\hline Niacin (mg) & 1706 & $86 \cdot 3$ & 865 & $88 \cdot 4$ & 841 & $84 \cdot 4$ & 0.0096 \\
\hline Vitamin $\mathrm{B}_{6}(\mathrm{mg})$ & 822 & $41 \cdot 5$ & 409 & $41 \cdot 8$ & 413 & $41 \cdot 4$ & 0.8735 \\
\hline Vitamin $B_{12}(\mu \mathrm{g})$ & 1299 & $65 \cdot 7$ & 678 & $69 \cdot 3$ & 621 & $62 \cdot 3$ & 0.0011 \\
\hline Folate $(\mu \mathrm{g})$ & 1066 & $53 \cdot 8$ & 550 & $56 \cdot 2$ & 516 & $51 \cdot 8$ & 0.0485 \\
\hline
\end{tabular}

RAE, retinol activity equivalents.

${ }^{*}$ Adequacy is defined as one-third of the Dietary Reference Intake (i.e. the Estimated Average Requirement, EAR) for each nutrient. tDifferences were assessed using $\chi^{2}$ tests of association.

vitamin $\mathrm{B}_{12}$ and folate (Table 2). The adequacy of some micronutrients differed according to gender. A higher number of boys consumed adequate amounts of $\mathrm{Fe}$, thiamin, riboflavin, niacin, vitamin $\mathrm{B}_{12}$ and folate, while more girls consumed adequate amounts of vitamin A (Table 2).

Only one-third of all foods consumed at lunch were from school (school foods) such that total nutrient intakes from foods brought from home (home foods) were higher than those from school food. Median intakes of all micro- and macronutrients were significantly higher in home foods than in those purchased at school. However, the nutrient densities of school foods, which were calculated to standardize values from the two sources, were significantly higher for protein, fat, sugar, $\mathrm{Ca}, \mathrm{Mg}, \mathrm{K}, \mathrm{Zn}$, vitamin $A$, vitamin $D$, riboflavin, niacin, vitamin $B_{6}$ and vitamin $\mathrm{B}_{12}$ than the nutrient densities of foods from home (Table 3). In contrast, the nutrient densities for carbohydrates, fibre, Fe, vitamin $\mathrm{C}$, folate and $\mathrm{Na}$ were significantly higher in home foods compared with school foods.

There were no significant differences between the nutrient density of intakes for boys and girls for food items purchased from school. However, girls reported home-packed lunches with higher nutrient densities of carbohydrates, fibre, $\mathrm{K}$, vitamin $\mathrm{A}$ and vitamin $\mathrm{C}$ than boys (data not shown).

\section{Discussion}

The present study is the first one in Canada to evaluate the dietary quality of lunchtime foods consumed by elementary-school students that considers the source of the food (home $v$. school). Foods served at school were found to be of a higher nutritional quality than those brought from home, which is consistent with past reports ${ }^{(10,11,25-27)}$. A meta-analysis comparing British school meals and packed lunches also concluded that the nutritional quality of
Table 3 Comparison of mean nutrient density* of total food consumed at lunchtime by source among grade 5 and 6 children ( $n$ 1980) in elementary schools, Prince Edward Island, Canada

\begin{tabular}{|c|c|c|c|c|c|}
\hline \multirow[b]{2}{*}{ Nutrient } & \multicolumn{2}{|c|}{ School } & \multicolumn{2}{|c|}{ Home } & \multirow[b]{2}{*}{$P$ valuet } \\
\hline & Mean & SD & Mean & SD & \\
\hline Protein $(\mathrm{g})$ & $44 \cdot 4$ & $16 \cdot 6$ & $30 \cdot 9$ & $20 \cdot 4$ & $<0.0001$ \\
\hline Fat $(\mathrm{g})$ & $35 \cdot 5$ & $11 \cdot 5$ & $31 \cdot 1$ & $14 \cdot 6$ & $<0.0001$ \\
\hline Carbohydrates (g) & $126 \cdot 8$ & $37 \cdot 8$ & $152 \cdot 8$ & $44 \cdot 2$ & $<0.0001$ \\
\hline Sugar (g) & $84 \cdot 5$ & $52 \cdot 3$ & $68 \cdot 5$ & $53 \cdot 3$ & $<0.0001$ \\
\hline Fibre $(\mathrm{g})$ & $5 \cdot 6$ & $4 \cdot 8$ & $9 \cdot 1$ & $7 \cdot 4$ & $<0.0001$ \\
\hline $\mathrm{Fe}(\mathrm{mg})$ & $4 \cdot 3$ & $3 \cdot 1$ & $6 \cdot 8$ & $3 \cdot 7$ & $<0.0001$ \\
\hline $\mathrm{Ca}(\mathrm{mg})$ & $1203 \cdot 8$ & $741 \cdot 8$ & $375 \cdot 0$ & $293 \cdot 2$ & $<0.0001$ \\
\hline $\mathrm{Mg}(\mathrm{mg})$ & $156 \cdot 2$ & $56 \cdot 1$ & $114 \cdot 2$ & $64 \cdot 0$ & $<0.0001$ \\
\hline $\mathrm{K}(\mathrm{mg})$ & $2012 \cdot 0$ & $948 \cdot 4$ & $1179 \cdot 5$ & $809 \cdot 0$ & $<0.0001$ \\
\hline $\mathrm{Zn}(\mathrm{mg})$ & $5 \cdot 7$ & $2 \cdot 4$ & $3 \cdot 6$ & $2 \cdot 6$ & $<0.0001$ \\
\hline Vitamin A (RAE) & $611 \cdot 2$ & $980 \cdot 7$ & $197 \cdot 7$ & $876 \cdot 0$ & $<0.0001$ \\
\hline Vitamin D $(\mu \mathrm{g})$ & $9 \cdot 5$ & $7 \cdot 7$ & 0.78 & $2 \cdot 13$ & $<0.0001$ \\
\hline Vitamin C (mg) & $44 \cdot 5$ & $135 \cdot 2$ & $92 \cdot 6$ & $162 \cdot 3$ & $<0.0001$ \\
\hline Thiamin $(\mathrm{mg})$ & 0.72 & $0 \cdot 37$ & $0 \cdot 76$ & 0.47 & $<0.0001$ \\
\hline Riboflavin (mg) & $1 \cdot 94$ & $1 \cdot 10$ & $0 \cdot 80$ & 0.49 & $<0.0110$ \\
\hline Niacin (mg) & $14 \cdot 1$ & $5 \cdot 9$ & $13 \cdot 5$ & $10 \cdot 0$ & $<0.0150$ \\
\hline Vitamin $B_{6}(\mathrm{mg})$ & 0.62 & $0 \cdot 39$ & 0.56 & 0.46 & $<0.0001$ \\
\hline Vitamin $B_{12}(\mu \mathrm{g})$ & $4 \cdot 20$ & $3 \cdot 00$ & $1 \cdot 11$ & 1.95 & $<0.0001$ \\
\hline Folate $(\mu \mathrm{g})$ & $134 \cdot 5$ & $124 \cdot 6$ & $199 \cdot 5$ & $143 \cdot 3$ & $<0.0001$ \\
\hline $\mathrm{Na}(\mathrm{mg})$ & $1473 \cdot 1$ & $1503 \cdot 7$ & $2020 \cdot 8$ & $1648 \cdot 5$ & $<0.0001$ \\
\hline
\end{tabular}

RAE, retinol activity equivalents.

*Nutrient density is defined as the nutrient content in grams divided by the total energy content expressed in kJ (kcal) multiplied by $4184(1000)^{(24)}$. tDifferences were assessed using a Wilcoxon signed rank test.

packed lunches was poor compared with children's school meals ${ }^{(11)}$. The overall diet quality of children's lunches was low, with median intakes of $\mathrm{Mg}, \mathrm{K}, \mathrm{Zn}$, vitamins $\mathrm{A}, \mathrm{D}, \mathrm{C}, \mathrm{B}_{6}$, folate and fibre falling below recommended levels. The very high $\mathrm{Na}$ intakes are a significant concern and likely reflect the frequent inclusion of processed foods (e.g. cracker/ cheese/meat combination packs); analysis of food group intakes is included in a separate report. The poor nutritional quality of children's lunchtime intakes likely reflects the frequent inclusion of low-nutrient-dense foods in the packed lunches since two-thirds of student lunchtime food 
and beverage intakes came from home sources. This in turn may reflect, in part, the small scale and ad hoc nature of school lunch programmes in PEI and the lack of a national school meal programme.

Nutrient densities of foods brought from home were generally higher than those of foods purchased at school. One striking finding was that intakes of $\mathrm{Ca}$, vitamin $\mathrm{A}$ and vitamin $\mathrm{D}$ were all higher in foods/beverages purchased at school. This likely reflects higher milk intakes bought at school, since all PEI elementary schools participate in the PEI School Milk Program, and milk is most likely to be purchased at school rather than brought from home due to subsidized pricing ${ }^{(28)}$. However, although all schools offer a school milk programme, average participation rates are approximately $34 \%$ of students which is quite low. It is thus not surprising that children's median lunchtime intakes of $\mathrm{Ca}$ and vitamin $\mathrm{D}$ fell below the current dietary recommendations in spite of the School Milk Program being offered at all schools. Other studies evaluating lunch food sources have also noted that $\mathrm{Ca}$ is higher in school foods ${ }^{(8,9,11,27)}$. The nutritional quality of children's lunch items that are brought from home could be improved significantly by including more food and beverage items high in Ca such as yoghurt and cheese.

One limitation of the current study is that it included food intake data from only one meal within a single day's intake, and thus may not reflect children's usual intakes ${ }^{(8)}$. Nevertheless, this recording period was selected in order to minimize demands placed on schools and students participating, thereby gaining the cooperation and compliance of schools. It is also important to note that there is less variety in lunchtime menus offered at schools in PEI, which decreases the need for multiple days of recording. We minimized the amount of time between consumption and the assessment in order to enhance children's ability to accurately recall details of their lunchtime food and beverage intakes and increase the validity of the assessment ${ }^{(29)}$. Other sources of error, including those associated with the estimation of portion size and children's desire to provide socially desirable responses ${ }^{(30)}$, were minimized through training of research assistants and quality control procedures during coding and data entry. The small but significant differences according to the day that intakes were recorded may have resulted in a slight overestimation of inadequacy in this sample. Dietary adequacy was determined by comparing median nutrient intakes at lunch with one-third of the RDA - standards used both in the USA and Canada to assess overall dietary adequacy ${ }^{(24)}$. While we recognize that these standards were not meant to be used to evaluate a single meal, there were no other standards available that could be used to assess the dietary quality of the lunchtime food intakes. Furthermore, the EAR is also used to set nutrient standards in the USA for its national school lunch programme ${ }^{(23)}$.

The entire grade 5 and 6 student population from all PEI English-language elementary schools was invited to participate in the present study; approximately two-thirds completed the study. Given our $60 \%$ response rate, findings may be generalized to English grade 5 and 6 students in PEI.

\section{Conclusions}

The present study examined the nutritional composition of children's school lunches and compared the quality of foods purchased at school with those brought from home. The overall nutritional quality of lunches was poor, regardless of source.

Lunch food items purchased at school were generally higher in nutrient density than lunch food items brought from home. Of particular concern in the present study was the difference between the home and school lunch items in regard to $\mathrm{Ca}$ and vitamin $\mathrm{D}$. Lunch items purchased at school were significantly higher in both Ca and vitamin D than lunch items from home, likely reflecting the fact that all PEI elementary schools offer a subsidized school milk programme. However, the $\mathrm{Ca}$ and vitamin $\mathrm{D}$ composition of children's school lunches remains low, suggesting that children are not benefiting sufficiently from the milk programme. This finding suggests that one strategy to increase children's low $\mathrm{Ca}$ intakes could involve increased promotion of school milk programmes in an attempt to increase participation rates.

A second significant concern pertains to the very high $\mathrm{Na}$ content of the children's lunches, particularly in foods brought from home. Since approximately two-thirds of the foods in children's lunches were brought from home in the present study and these were lower in nutritional quality and higher in $\mathrm{Na}$ than foods offered at school, improving the dietary habits of school-aged children will require a collaborative effort from multiple stakeholders, with a particular focus on parents.

\section{Acknowledgements}

Funding for the present study was provided by the Canadian Institute for Health Research. There are no conflicts of interest to declare. J.P.T. and J.M.C. developed the research questions, conducted the analysis and drafted the first manuscript. D.G. advised on analysis. K.J.H. conducted the literature review, and revised the manuscript along with J.P.T. All authors advised with final analysis/conclusions as well as read and approved the final manuscript.

\section{References}

1. Public Health Agency of Canada (2011) Curbing childhood obesity: an overview of the federal, provincial and territorial framework for action to promote healthy weights. http://www.phac-aspc.gc.ca/hp-ps/hl-mvs/framework-cadre/ intro-eng.php (accessed July 2011). 
2. Wojcicki JM \& Heyman MB (2006) Healthier choices and increased participation in a middle school lunch program: effects of nutrition policy changes in San Francisco. Am J Public Health 96, 1542-1547.

3. World Health Organization (2008) School Policy Framework: Implementation of the WHO Global Strategy on Diet, Physical Activity and Health. Geneva: WHO.

4. Veugelers PJ \& Schwartz ME (2010) Comprehensive school health in Canada. Can J Public Health 101, Suppl. 2, S5-S8.

5. McKenna ML (2010) Policy options to support healthy eating in schools. Can J Public Health 101, Suppl. 2, S16-S17.

6. Vecchiarelli S, Takayanagi S \& Neumann C (2006) Students' perceptions of the impact of nutrition policies on dietary behaviors. J Sch Health 76, 540-542.

7. Raine K (2004) Overweight and Obesity in Canada: A Population Health Perspective. Ottawa, ON: Canadian Population Health Initiative, Canadian Institute for Health Information.

8. Townsend N, Murphy S \& Moore L (2011) The more schools do to promote healthy eating, the healthier the dietary choices by students. J Epidemiol Community Health 65, 889-895.

9. Hur I, Burgess-Champoux T \& Reicks M (2011) Higher quality intake from school lunch meals compared with bagged lunches. Infant Child Adolesc Nutr 3, 70-75.

10. Johnson CM, Bednar C, Kwon J et al. (2009) Comparison of nutrient content and cost of home-packed lunches to reimbursable school lunch nutrient standards and prices. $J$ Child Nutr Manage 33, 1-8.

11. Evans CEL, Cleghorn CL, Greenwood DC et al. (2010) A comparison of British school meals and packed lunches from 1990 to 2007: meta-analysis by lunch type. Br J Nutr 104, 474-487.

12. MacLellan D, Holland A, Taylor J et al. (2010) Barriers and facilitating factors in school nutrition policy implementation: student and parent perspectives. Can J Diet Pract Res 71, 172-177.

13. Cullen K, Watson K \& Zakeri I (2007) Middle School Student Lunch Consumption: Impact of Food Source. USDA-ERS Report no. 30. http://www.ers.usda.gov/publications/ccr30/ ccr30.pdf (accessed November 2009).

14. Bere E \& Klepp K (2005) Correlates of fruit and vegetable intake among Norwegian school children: parental and self reports. Public Health Nutr 7, 991-998.

15. Van Strein T, van Niekerk R \& Ouwens MA (2009) Perceived parental food controlling practices are related to obesogenic or leptogenic child life style behaviors. Appetite 53, 151-154.
16. Baxter SD, Thompson WO, Davis HC et al. (1997) Impact of gender, ethnicity, meal component, and time interval between eating and reporting on accuracy of fourthgraders' self-reports of school lunch. J Am Diet Assoc 97, 1293-1298.

17. Lytle LA, Himes JH, Feldman $\mathrm{H}$ et al. (2002) Nutrient intake over time in a multi-ethnic sample of youth. Public Health Nutr 5, 319-328.

18. Domel SB, Baranowski T, Leonard SB et al. (1994) Accuracy of fourth- and fifth-grade students' food records compared with school-lunch observations. Am J Clin Nutr 59, 1 Suppl., 218S-220S.

19. Health Canada (2007) Canadian nutrient file. http://www. hc-sc.gc.ca/fn-an/nutrition/fiche-nutri-data/index_e.html (accessed March 2011).

20. Evers S, Taylor J, Manske S et al. (2001) Eating and smoking behaviours of school children in southwestern Ontario and Charlottetown, PEI. Can J Public Health 92, 433-436.

21. Godin G (2008) CANDAT: A nutrient calculation system (version 7.0). http://www.candat.ca/ (accessed March 2011).

22. Institute of Medicine (2006) Dietary Reference Intakes: The Essential Guide to Nutrient Requirements. Washington, DC: The National Academies Press.

23. American Dietetic Association (2011) Practice paper of the American Dietetic Association: using the dietary reference intakes. J Am Diet Assoc 111, 762-770.

24. Drewnowski A (2005) Concept of a nutritious food: toward a nutrient density score. Am J Clin Nutr 82, 721-732.

25. Pearce J, Harper C, Haroun D et al. (2011) Key differences between school lunches and packed lunches in primary schools in England in 2009. Public Health Nutr 14, 1507-1510.

26. Rees G, Richards C \& Gregory J (2008) Food and nutrient intakes of primary school children: a comparison of school meals and packed lunches. J Hum Nutr Diet 21, 42-427.

27. Martin CK, Thomson JL, LeBlanc MM et al. (2010) Children in school cafeterias select foods containing more saturated fat and energy than the Institute of Medicine Recommendations. J Nutr 140, 1653-1660.

28. Cullen T (2010) President's Report 2009-2010. Charlottetown, PEI: Prince Edward Island School Milk Foundation Ltd.

29. Foster E, O'Keefe MO, Matthews JNS et al. (2008) Children's estimates of food portions size: the effect of timing of dietary interview on the accuracy of children's portion size estimates. BrJ Nutr 99, 185-190.

30. Gibson RS (2005) Principles of Nutritional Assessment, 2nd ed. New York: Oxford University Press. 